\title{
The Effects of Attitudes, Pedagogical Practices and Teachers' Roles on the Incorporation of ICT into the School Curriculum
}

\author{
Margaret Cox \\ King's College London, Franklin-Wilkins Building, Stamford St, London SE1 9NN, \\ mj.cox@kcl.ac.uk
}

\begin{abstract}
Research conducted at King's College into the attitudes of teachers towards ICT and their motivation for using it in their teaching has shown that these are influenced by their own pedagogies. However when ICT is involved a conflict may arise. This conflict derives from preconceived ideas about what is expected of teachers when using ICT in their lessons, and how this may be alien to their most comfortable pedagogical practices applied in more traditional non-ICT class activities. Attitude theories and empirical evidence lead to an important research question: do the attitudes of the teachers towards ICT, and the types of ICT use, affect the roles they adopt and their pedagogical practices when persuaded to use ICT in the classroom? The paper will present evidence from previous research of the relationship between the types of ICT use, teachers' attitudes to using ICT and the effects on their pedagogical practices.
\end{abstract}

\section{FACTORS AFFECTING THE INTEGRATION OF ICT IN THE CLASSROOM}

Although much of the earlier research evidence (Cox, 1993a, 1993b; Harrison et al., 2002; Preston et al., 2000; Watson, 1993) showed that one reason for the reluctance of teachers to use ICT was insufficient or inappropriate training, research into the effectiveness of teacher training has shown that many courses did not in fact lead to a change in teachers' practices nor to sustained uptake of ICT in their schools (e.g. see Bliss et al., 1986; Hay McBer, 2000; Passey \& Samways, 1997). This is often because teachers do not have a clear and coherent sense of the reasons for

The original version of this chapter was revised: The copyright line was incorrect. This has been corrected. The Erratum to this chapter is available at DOI: 10.1007/978-0-387-35701-0_35 
educational change (Desforges, 1995; Fullan, 1991; Somekh \& Davies, 1991; Underwood, 1988). Additionally, according to the theory of planned behaviour (Ajzen, 1991), human behaviour, including the use of ICT, is guided by beliefs about: the likely outcomes of the behaviour; the normative expectations of others; and the presence of factors that may facilitate or impede the performance. It is also influenced by teachers' perceptions of what ICT means as explained by the definition given in 1.1 . The very nature of the ICT medium itself will influence the other major factors affecting the successful integration by teachers.

A very important aspect of ICT regarding how it might influence pedagogical practices and teachers' roles, which is often not addressed by teachers or researchers, is the representations which different ICT environments present to the teacher and the learner. Extensive research by Mellar et al. (1994) and Cheng et al. (2001) has provided a sound theoretical basis for further research into the effects of different ICT representations in education. For example, Cheng et al.'s work into recodifying knowledge has produced a representational epistemology (REEP) which addresses the fundamental roles and functions that representational systems have regarding teaching and learning. In order that teachers can use different ICT environments to teach their pupils they need to understand the scope and meaning of different ICT representational systems (Ainsworth, Bibby \& Wood, 1997). For example, in the case of many science topics, using computer graphics would require the teacher to understand the effects of switching from syntactic rule governed notational systems to diagrammatic models. A simple example of this would be when teachers use spreadsheets for modelling in primary schools. At the age of 10 pupils may be able to understand the purpose and structure of a simple table but not the concept of a spreadsheet cell being able to 'contain' text, or a single number, let alone an equation (Cox, 2003). There is an extensive psychology research literature about the problems with different representational systems and the effects they have on students' learning and therefore on teachers' roles.

It is clear from the evidence and discussion presented above that the integration of ICT by teachers and the consequent variation in their teaching roles will be strongly influenced by their attitudes towards ICT and their own pedagogical beliefs. Theories relating to these two factors, which have been developed and evaluated, are discussed in the following sections.

\subsection{Attitude Theories and Attitudes of Teachers to Using ICT}

The theory of planned behaviour, based on the theory of reasoned action was developed by Ajzen and colleagues (1988). According to this theory, 
shown in Figure 1, behaviour is determined by an intention to engage in that behaviour. In turn, intention to perform certain behaviours is affected by three factors: attitude towards the behaviour, subjective norm and perceived behavioural control.

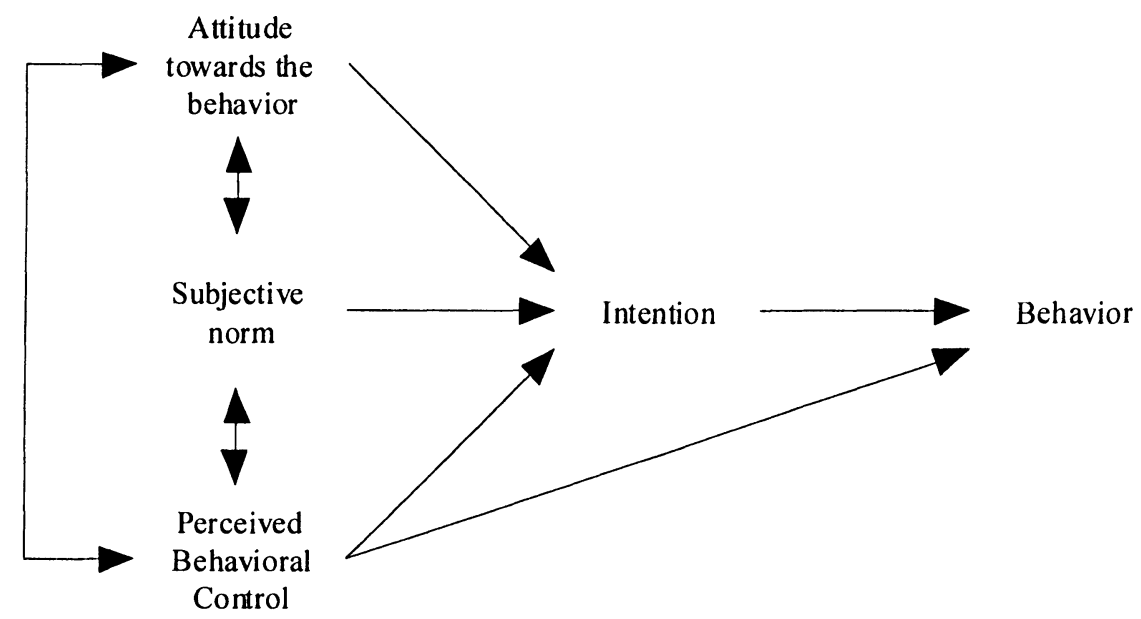

Figure 1. Theory of planned behaviour (Ajzen, 1988, p. 133)

Applying this theory to the motivation of teachers to use ICT, the use of ICT in teaching will depend upon the teachers' intention to use ICT. This will, in turn, be influenced by the teachers' attitudes towards using ICT in their teaching. In relation to teachers, these attitudes might include perceptions concerning the effects on their role as a teacher, the impact on pupils' motivation, the impact on the teachers' influence in the school, how the behaviour might affect other teachers and so on. Furthermore, as was explained above, we might expect that teachers' attitudes towards using ICT will be influenced by their perceptions of what ICT means, the information they have about the value of ICT, their previous experiences and expertise in using ICT and the expectation that it will contribute to pupils' learning.

The second component included in the theory of planned behaviour, subjective norm, represents the perceived social pressures experienced by the individual, i.e. people's beliefs concerning others' attitudes towards the behaviour and the perceived importance of these attitudes. Regarding ICT uptake by teachers, this would be the teachers' perception of the social pressure to use or not use ICT. In particular, they may be influenced by the views of their colleagues, pupils, parents or governors. In many previous studies in other domains, attitudes have proved to be more influential than 
subjective norms (Ajzen, 1988). However, in the case of using ICT in one's teaching, because of the immense and growing pressures from educational reforms, parents, the media, and so on, it is likely that subjective norm will have a greater impact on teachers' use of ICT.

The perceived behavioural control component refers to the extent to which teachers believe themselves to be capable of using ICT in their teaching. This "is assumed to reflect past experience as well as anticipated impediments and obstacles" (Ajzen, 1988, p. 132). In relation to the use of ICT in teaching, teachers may feel incapable of using ICT for a number of reasons. For example, they may lack confidence in their ICT skills to be able to help pupils in a lesson, they may not be able to adjust their teaching style to accommodate ICT, or they may not know how to use ICT effectively in their subject.

Davis, Bagozzi and Warshaw (1989) developed a "theory of action relating to reasons", technology acceptance model, based on the work of Fishbein and Ajzen, to explain why some people use computers and others do not. According to their model, shown in Figure 2, the perceived usefulness and ease of use of the technology will affect a person's attitude towards using it. Furthermore, these factors are influenced by external variables. As with Fishbein and Ajzen's model, attitudes affect intentions to use ICT, which, in turn, affect actual use. Davis, Bagozzi and Warshaw tested this model with 107 adult users, who had been using a managerial system for 14 weeks. They found that people's computer use was predicted by their intentions to use it and that perceived usefulness was also strongly linked to these intentions.

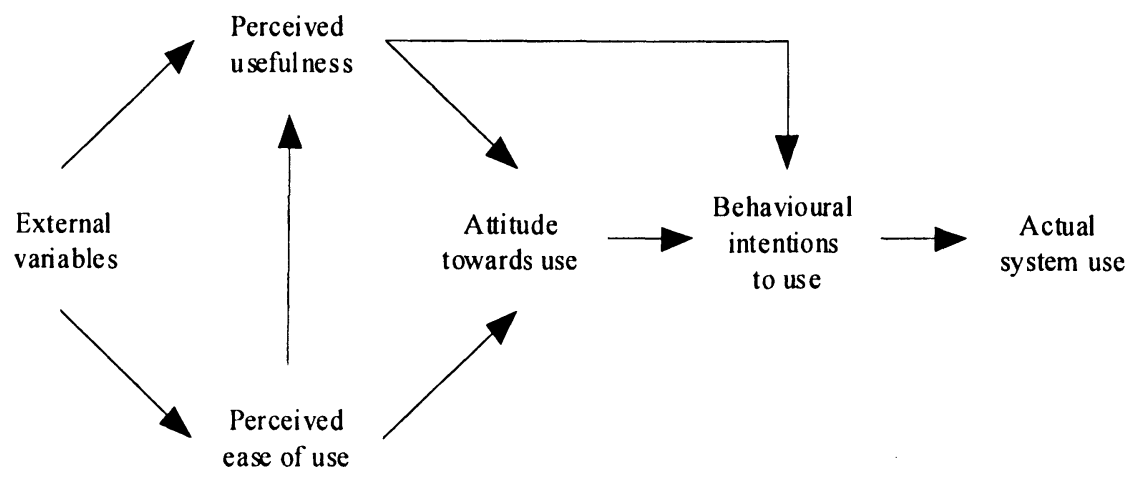

Figure 2. The technology acceptance model (Davis, Bagozzi \& Warshaw, 1989)

There is a growing body of research evidence showing that ICT makes teachers' lessons more interesting, more enjoyable, and more important to 
the learners (Preston, Cox \& Cox, 2000) and increases self-confidence (Gardner, Dukes \& Discenza, 1993). Using evidence from previous research, a number of factors have been identified by Preston, Cox and Cox (2000) that relate to each of the components of this model which are explained below.

\subsubsection{External variables}

In Davis, Bagozzi and Warshaw's model, the external variables represent the many influences on people that may affect their attitudes and behaviour. For teachers these influences may include:

- requirements of the national curriculum or national guidelines;

- local education authority policies;

- school policies on using ICT;

- responsibilities of the teacher;

- training received;

- pressure from parents and pupils;

- opinions of colleagues;

- membership of professional organisations;

- changes in society, including the rapid growth in the use of the Internet and ICT in general.

Other factors, such as the New Opportunities Fund for the training of teachers in the UK and the Teacher Training Agency's requirements concerning the ICT skills for new teachers in England and Wales (TTA, 1999), may have an impact on teachers' ICT use in the future.

\subsubsection{Perceived ease of use}

There are a number of factors that have been identified by previous studies that relate to the perceived ease of use of ICT. Watson (1993), Loveless (2001), Cox (2003) and other researchers have shown that teachers need a wide range of skills and competencies in order to find it easy to use ICT. For example, previous research has shown that teachers who felt confident in using ICT perceived it as being easier to use in their lessons, whereas teachers who experienced technical difficulties using a particular piece of software perceived using ICT in their lessons as being more difficult (Cox, 1997a; Preston, Cox \& Cox, 2000; Watson, 1993). The factors identified by previous research relating to perceived ease of use of ICT include:

- ability to use software/hardware;

- confidence in using ICT; 
- ability to control the class;

- ability to think of new lesson ideas;

- perceived impact on the content of lessons.

\subsubsection{Perceived usefulness}

If teachers perceive ICT to be useful to them, their teaching and their pupils' learning, then according to the evidence of previous studies (e.g. see Gardner, Dukes \& Discenza, 1993; Preston, Cox \& Cox, 2000) they are more likely to have a positive attitude to the use of ICT in the classroom. Preston, Cox and Cox (2000) identified a number of factors that relate to teachers' perceived usefulness of ICT:

- whether or not the lessons are made more interesting, enjoyable, or diverse for the teacher;

- whether or not the lessons are made more difficult for the teacher;

- impact on the presentation of materials for lessons;

- perceived contribution to administrative tasks;

- impact on pupils' motivation and learning;

- impact on the teacher's confidence;

- impact on the teacher's prestige;

- perceived effect on career prospects.

As with perceived ease of use, some of these factors add to the perceived usefulness of ICT whereas others detract from it. For example, if a teacher feels that using ICT makes lessons more difficult, then the perceived usefulness will be reduced, whereas if a teacher feels that it makes it more interesting, perceived usefulness will be increased. Teachers' attitudes to many of these factors will depend upon how easy they perceive using ICT to be, both for personal use and for use in teaching. This in turn will be influenced by their perceptions of ICT and how this might affect their ability to use it in their teaching. According to Davis et al's model, the greater the perceived usefulness and perceived ease of use are, the more positive the attitudes of teachers will be to the use of ICT and consequently, the more likely they will be to use ICT in their teaching.

Preston, Cox and Cox's study (2000), which was based on these theories, obtained statistical evidence of the relationship between the ICT abilities of the teacher and their perceptions of the value of ICT to pupils' learning, although they also found that the range of ICT uses by most of the teachers in the study was very limited and did not cover all of those included in definitions of ICT.

The models described above are the most widely used to measure the effects of attitudes on teachers' uptake and uses of ICT, but as yet there is little reported research which delves into the attitudes of teachers to specific uses of ICT as defined in 1.1 above. Extensive empirical evidence has 
supported these theories described above, and shown that teachers who have taken up the use of ICT in teaching are frequently motivated by their positive perceptions of the value of ICT to their pupils and to their own professional development. On the other hand, for teachers who are reluctant to use ICT, factors such as insufficient resources, lack of confidence and inability to adopt new practices have been identified as important reasons for nonadoption. The evidence from research into the effects of teachers' attitudes on ICT uptake and use discussed above clearly indicates that teachers uses of ICT will also be affected by their perceptions of the pedagogical practices required to integrate ICT appropriately in their teaching.

\subsection{Theories of Pedagogy and Teachers Practices}

The research evidence that has been referred to above into the attitudes of teachers towards ICT and their motivation for using it in their teaching, has shown that these are influenced by their own pedagogies yet when ICT is involved a conflict arises. This conflict arises from preconceived ideas about what is expected of teachers when using ICT in their lessons, and how this may be alien to their most comfortable pedagogical practices applied in more traditional non-ICT class activities, therefore teachers' pedagogical reasoning plays an important part in determining whether or not a teacher will use ICT and the roles he or she may adopt when using ICT.

\subsubsection{Theories of pedagogy}

A review of the literature on how teachers' experiences affect their theoretical knowledge of teaching by Desforges (1995) has shown that the effectiveness of teachers adopting new methods in their teaching is dependent on their attitudes towards improving their professional development, their knowledge of the effects of their teaching on their pupils' learning and the type and extent of teacher training they had experienced. Previous research has also shown that the way in which teachers use ICT depends upon their perceptions of the role and value of ICT and on their other teacher pedagogies (Cox 1997a; Watson, 1993).

Models of teachers' pedagogies have been examined by Loveless (2001) including the model developed by Leach and Moon of professional knowledge (Leach \& Moon, 2000) shown in Figure 3. 


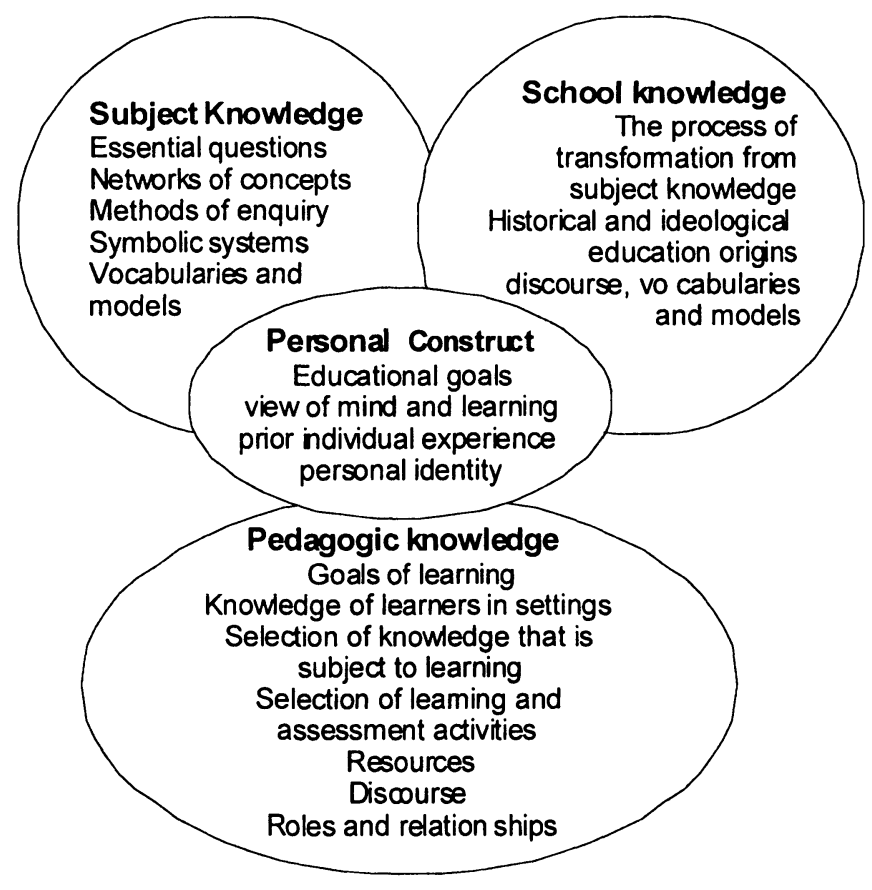

Figure 3. Leach and Moon's model of professional knowledge (Loveless, 2001, p. 33)

Loveless supports the arguments of Leach and Moon that "pedagogy can be described as an expression of teachers' professional knowledge in which a number of dimensions interact within a broader socio-cultural context for learning and practice" (Loveless, 2001, p. 30). This model builds on the work of Shulman (1987) whose framework acknowledges the interaction between pedagogic knowledge, subject knowledge, school knowledge and teacher's personal beliefs. Shulman focuses on knowledge rather than ideas and beliefs but, in addition to the large body of attitudinal evidence referred to above, there is evidence that teachers' ideas, beliefs and values may also influence practice (Fang, 1996). These ideas, beliefs and values in turn are influenced as explained earlier by teachers' attitudes, their subjective norms and perceived behavioural control (see Section 1.1 above).

An examination by Webb (2002) of pedagogical reasoning relating to the teaching of ICT as a subject, and the research conducted by Loveless (2001) into teachers' pedagogical practices support the need for researchers and practitioners to distinguish the difference between pedagogy and practice. The conclusion from investigations into pedagogical reasoning confirms the attitudinal psychological research and extensive educational work conducted 
by Fullan (1991), Desforges (1995) and others that the ability of teachers to adopt ICT in their teaching will depend on a complex range of interrelated factors and will vary according to the types of ICT use being adopted, the subject knowledge of the teacher and the pedagogic knowledge relating to ICT. This applies not only to classroom practices but also to methods of pupil assessment, progression and the interrelationship with other educational experiences and in other educational settings. There have been many research studies investigating the actual practices of teachers when using ICT but most of them have not been able to investigate all these factors for one group of teachers.

\subsubsection{Pedagogical practices}

There are many publications listing different pedagogical practices when using ICT (see, for example, Loveless, 2001; QCA, 2001; TTA, 1999; Webb, 2002). It has been established by these that teachers' practices, including the roles they adopt, will depend upon the following:

- Definitions of pedagogies specifically associated with ICT;

- The types of ICT, as explained in the definition given earlier in 1.1.

- The ICT representations, which are produced by different ICT environments, will be influenced by the hardware as well as the software.

- The level of use of ICT, since this will also influence the pedagogical practices of the teachers; a useful framework for categorisation of level of use is Loucke's Level of Use Model (Loucks et al., 1998), which could be modified for different types of ICT.

The most basic pedagogical practices associated with using ICT are:

- The selection of the ICT resource;

- The organisation of the ICT resource;

- The planning of the lesson;

- The organisation of the lesson, including lesson structure and pupil grouping;

- Teacher interventions, roles adopted;

- Assessment of the pupils;

- Follow up activities.

If we consider the models of pedagogy referred to above and the empirical evidence presented earlier, then these practices listed above are often achieved inadequately because of the limited pedagogical knowledge of the teacher relevant to using ICT. Webb (2002) identified a range of pedagogical issues, shown in Table 1. 
Table 1. Issues affecting knowledge transformation in the ICT teaching community (from Webb, 2002, p. xxx)

\begin{tabular}{ll}
\hline Categories of Knowledge & $\begin{array}{l}\text { Issues affecting availability of knowledge in the ICT } \\
\text { teaching community }\end{array}$ \\
\hline Current knowledge & $\begin{array}{l}\text { Some ICT teachers have inadequate content knowledge. } \\
\text { Some ICT teachers are expected to comprehend not only } \\
\text { content knowledge for ICT but also how this knowledge } \\
\text { relates to the content of other subjects so that both can be } \\
\text { taught in an integrated way. } \\
\text { Less well-defined for ICT than for other subjects. }\end{array}$ \\
Pedagogical content knowledge & $\begin{array}{l}\text { Subject specific interpretations are less well-defined for } \\
\text { ICT than for other subjects. }\end{array}$ \\
Knowledge of learners & $\begin{array}{l}\text { Limited research base of students' problems and } \\
\text { misconceptions in ICT. }\end{array}$ \\
Curriculum knowledge & $\begin{array}{l}\text { The collective curriculum knowledge of ICT teachers is } \\
\text { less extensive than for other subjects. } \\
\text { The importance of using software in ICT makes } \\
\text { curriculum knowledge more complex for ICT than for } \\
\text { other subject areas. } \\
\text { The scope and possibilities are changing rapidly as } \\
\text { technology develops. }\end{array}$ \\
\hline
\end{tabular}

Although these issues have been identified for ICT teachers rather than teachers using ICT in other subjects, they have been shown by many previous research studies, referred to earlier, to apply equally to teachers attempting to use ICT in their teaching. For example, if we consider the use of computer based modelling in physics, then many physics teachers have insufficient knowledge of the advanced physics content which could be taught through computer based modelling at school level, and often have very limited pedagogic knowledge of how computer based modelling could be included in the physics curriculum (Cox, 2000).

\section{THE EFFECTS OF TEACHERS' ATTITUDES AND PEDAGOGICAL KNOWLEDGE AND PRACTICES ON THE ROLE OF THE TEACHER}

Research into the effects of ICT and attainment and the uptake of ICT in education has shown that teachers' pedagogy significantly influences the way in which ICT is used in the classroom and therefore how this will affect pupils' learning. For example, an earlier study by Underwood (1988), who investigated the pedagogies of teachers using information handling packages in twelve primary schools and six secondary schools, found that many 
teachers believed that when using ICT in their lessons, their role would be more one of classroom manager and facilitator in the learning situation, than the pivotal focus of the classroom. Evidence of this teacher expectation, of withdrawing from a leading role in the classroom when using ICT, has been reported earlier by several researchers including Hoyles, Sutherland and Evans (1986), who found that when pupils were given the task of using LOGO in mathematics, the teachers expected to withdraw from guiding the children in selecting the learning tasks. They found there to be considerable gains in terms of motivation from the pupils deciding upon their own activities. Recent research has confirmed that this is still the practice in many classrooms, although there is now a rapidly growing practice of teachers communicating with pupils through the Internet and thereby engaging with the pupils on a more individual basis, sometimes more frequently than in a traditional classroom (Rees, 2002).

These studies and the empirical evidence presented earlier show that the role of "guide alongside" adopted by some teachers takes no account of the ways in which the ICT learning experience may differ from what is expected due to different ICT representations, therefore teachers may need to adopt many different types of roles according to the types of ICT use, curriculum content and so on. This argument assumes that the nature of the ICT activity should influence the role of the teacher. However the research into attitudes and teachers' practices discussed earlier shows that it may be that many teachers are able to only adopt only certain roles to accommodate their perceptions of ICT and confidence (or lack of it) with particular applications. In other words, the 'guide alongside' role may be adopted by teachers who have little or no idea of what the ICT environment is teaching the pupils. All the evidence presented in this paper and elsewhere clearly supports the argument that teachers need to adopt a very strong leadership role with pupils using ICT in order that pupils can benefit from the experience.

\section{CONCLUSION}

In summary, to address the question: "Do attitudes, pedagogical practices and teachers' roles need to change to enable them to incorporate ICT in the curriculum?" the review of attitudinal and pedagogical research has raised a number of issues that need further research. The evidence from the literature has shown that:

- A positive attitude towards using ICT may depend upon the types of ICT which the teacher feels confident to use with pupils, therefore 
further research into teachers' attitudes and behaviour involving teachers using a wide range of ICT types needs to be conducted;

- A negative attitude towards using ICT can be caused by a lack of understanding of the pedagogical theories relating to ICT;

- The types of ICT being used may influence the roles which teachers adopt in the classroom which in turn are affected by the teachers' pedagogies;

- Teachers pedagogies may be varied and inconsistent when using ICT, often due to a lack of understanding of the role and function of the ICT activity;

- There can be a conflict between teachers maintaining a positive attitude towards using ICT in their teaching, and pressures to extend the range and uses of ICT in the curriculum.

Evidence from this review of previous research studies shows that teachers' positive attitudes towards ICT in their teaching often exist when the uses of ICT are very limited. Therefore there may be an important relationship needing further investigation, which is the effects of the types of ICT use on teachers' attitudes and practices, and vice-versa. A consequence of this relationship is that for teachers who are whole heartedly adopting the 'guide alongside' approach to using ICT in their lessons, the ICT uses may be of limited educational value and very often all the previous good pedagogical practices go out of the window.

\section{REFERENCES}

Ainsworth, S. A., Bibby, P. \& Wood, D. J. (1997). Information technology and multiple representations: new opportunities - new problems. Journal of information Technology in Teacher Education, 6(1), 93-104.

Ajzen, I. (1988). Attitudes, Personality and Behavior. Milton Keynes: Open University Press.

Ajzen, I. (1991). The theory of planned behavior. Organizational Behavior and Human Decision Processes, 50, 179-211.

Bliss, J., Chandra, P. A. J. \& Cox, M. J. (1988). Introducing computers into a school Management issues. Computers and Education, 12(1), 57-61.

Cheng, P. C-H., Lowe, R. K., \& Scaife, M. (2001). Cognitive science approaches to diagrammatic representations. Artificial Intelligence Review, 15(1-2), 79-94.

Cox, M. J. (1993a). Information technology resourcing and use. In D. M. Watson (Ed.), Impact - An Evaluation of the Impact of the Information Technology on Children's Achievements in Primary and Secondary Schools. London: King's College.

Cox, M. J. (1993b). Technology enriched school project - The impact of information technology on children's learning. Computers and Education, 21(1/2), 41-49.

Cox, M. J. (1997a). Identification of the changes in attitude and pedagogical practices needed to enable teachers to use information technology in the school curriculum. In D. Passey \& B. Samways (Eds), Information Technology Supporting Change through Teacher Education (pp. 87-94). IFIP. London: Chapman \& Hall. 
Cox, M. J. (2000). Information and communication technologies: Their role and value for science education. In M. Monk \& J. Osborne (Eds), Good Practice in Science Teaching What Research Has to Say. UK: Open University Press.

Cox, M. J. (2003, in press). How do we know that ICT has an impact on children's learning? A review of techniques and methods to measure changes in pupils' learning promoted by the use of ICT. In G. Marshall \& J. Katz (Eds), Selected Proceedings from Learning with Technologies in School, Home and Community. Massachusetts: Kluwer.

Davis, F. D., Bagozzi, R. P. \& Warshaw, P. R. (1989). User acceptance of computer technology: A comparison of two theoretical models. Management Science, 35(8), 9821003.

Desforges, C. (1995). How does experience affect theoretical knowledge for teaching? Learning and Instruction, 5, 385-400.

Fang, Z. (1996). A review of research on teacher beliefs and practices. Educational Research, 38(1), Spring.

Fullan, M. G. (1991). The New Meaning of Educational Change. London: Cassell.

Gardner, D. G., Dukes, R. L. \& Discenza, R. (1993). Computer use, self-confidence, and attitudes: A causal analysis. Computers in Human Behaviour, 9, 427-440.

Harrison, C., Comber, C., Fisher, T., Haw, K., Lunzer, E., McFarlane, A., Mavers, D., Scrimshaw, P., Somekh, B. \& Wating, R. (2002). ImpaCT2: The Impact of Information and Communication Technologies on Pupil Learning and Attainment. BECTa and DfES. London: DfES Publications.

Hay McBer (2000). Research into Teacher Effectiveness: A Model of Teacher Effectiveness. Report to the Department for Education and Employment - June. London: DfEE.

Hoyles, C., Sutherland, R. \& Evans, J. (1986). Using LOGO in the mathematics classroom. What are the implications of pupil devised goals? Computers and Education, 10(1), 61-72.

Leach, J. \& Moon, B. (2000). Pedagogy, ICT and Teachers' Professional Knowledge. Paper presented at the British Educational Research Association Conference, Cardiff, September.

Loveless, A. (2001). An interaction between primary teachers' perceptions of information and communication technology (ICT) and their pedagogy. $\mathrm{PhD}$ Thesis, Brighton University.

Mellar, H., Bliss, J., Boohan, R., Ogborn, J. \& Tompsett, C. (Eds) (1994). Learning with Artificial Worlds: Computer Based Modelling in the Curriculum. London: The Falmer Press.

OFSTED (1995). Information Technology: A Review of Inspection Findings 1993/94. London: HMSO.

Passey, D. \& Samways, B. (Eds) (1997). Information Technology Supporting Change through Teacher Education (pp. 87-94). IFIP. London: Chapman \& Hall.

Preston, C., Cox, M. J. \& Cox, K. M. J. (2000). Teachers as Innovators: An Evaluation of the Motivation of Teachers to Use Information and Communications Technologies. London: King's College/Mirandanet.

QCA (2001). Information and Communication Technology: A Scheme of Work for Key Stage 3. London: Qualifications and Curriculum Authority.

Rees, R. (2002). Second year teacher candidates reflect on information technology in Ontario secondary schools: How it is being used and the challenges it presents. Technology, Pedagogy and Education, 2, 143-160.

Shulman, L. (1987). Knowledge and teaching: Foundations of the new reform. Harvard Educational Review,57, 1-22.

Somekh, B. \& Davies, R. (1991). Towards a pedagogy for information technology. The Curriculum Journal, 2(2), 153-170. 
Teacher Training Agency (1999). The Use of ICT in Subject Teaching: Expected Outcomes for Teachers in England, Wales and Northern Ireland. London: Teacher Training Agency.

Underwood, J. (1988). An investigation of teacher intents and classroom outcomes in the use of information-handling packages. Computers and Education, 12(1), 91-100.

Watson, D. M (Ed.) (1993). The ImpacT Report - An Evaluation of the Impact of Information Technology on Children's Achievements in Primary and Secondary Schools. London: King's College.

Watson, D. \& Tinsley, D. (1995). Integrating Information Technology into Education. London: Chapman \& Hall.

Webb, M. E. (2002). Pedagogical reasoning: issues and solutions for the teaching and learning of ICT in secondary schools. Education and Information Technologies, 7(2), 237-256. 